SYSTEMATIC ERRORS IN ENGINEERING EXPERIMENTS 
By the some author

A Background to Engineering Design 


\section{SYSTEMATIC ERRORS IN ENGINEERING EXPERIMENTS}

\section{PETER POLAK}

Department of Mechanical Engineering,

University of Sheffield 
(C) Peter Polak 1979

All rights reserved. No part of this publication may be reproduced or transmitted, in any form or by any means, without permission.

First published 1978 by

THE MACMI LLAN PRESS LTD

London and Basingstoke

Associated Companies in Delhi Dublin

Hong Kong Johannesburg Lagos Melbourne

New York Singapore and Tokyo

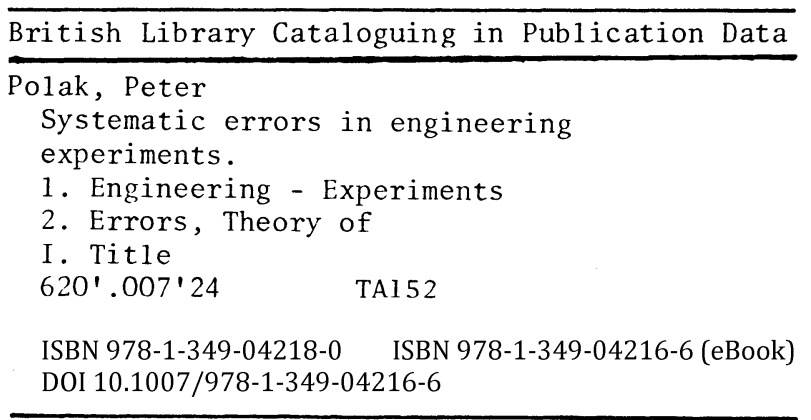

This book is sold subject to the standard conditions of the Net Book Agreement.

The paperback edition of this book is sold subject to the condition that it shall not, by way of trade or otherwise, be lent, resold, hired out, or otherwise circulated without the publisher's prior consent in any form of binding or cover other than that in which it is published and without a similar condition including this condition being imposed on the subsequent purchaser. 


\section{CONTENTS}

Preface

Acknowledgments

Symbols

1. TYPES OF ERROR

Systematic versus random errors. Consistency, repeatability, acceptable errors in industry. Simple electrical examples, d.c. and a.c.

2. TEMPERATURE MEASUREMENT

Thermal shunting errors. Thermocouples: laboratory and industrial set-ups, cold junction compensation, resistance correction, new data on conduction losses. Compensating cables. Galvanometers versus potentiometers. Radiation problems. Kinetic heating effects. Mercury-in-glass thermometers, stem correction and zero errors. A common ice-pot error. Boilingpoint error, superheat, barometric correction. Resistance and radiation methods. Melting indicators. Industrial recorders.

3. STATIC MECHANICAL PROPERTIES

Machine extension versus gauge-length extension. Discussion of yielding in long and short specimens. Bending tests, local buckling in fibrous materials, friction errors, large deflection errors, end errors in cantilevers, non-linearity in plastics, thermoelastic property of rubber.

4. DYNAMIC MECHANICAL PROPERTIES

Stress gradient, grain size, residual stress due to prior load. Evidence from industry and tests. Constant load and constant deflection tests, relevance to real structures. Transfer of energy from machine to specimen. Chain-like and rope-like structures contrasted. Adiabatic impacts contrasted with likely loading in machinery. Inertia and overshoot.

5. FLOW MEASUREMENT

Quantity and time methods. Timing errors, tank and float errors. Orifice and venturi meters, typical coefficients. Sources of error. Pulsating flow, viscous meter and errors. Pitot-static tube errors illustrated by photographs. Wall tapping error example. Hints on flow-visualisation, local accelerations of tracer particles. 
Size, density, volume of irregular or granular solids, speed, stroboscope errors. Pressure gauges and calibration, dynamic pressure problems, load transfer errors in force measurements. Strain-gauges.

7. TEST RIG PROBLEMS

Friction and deflection errors, good and bad kinematic design. Distributed loads. Force-free deflection measurement by Solex gauge.

8. GAS ANALYSIS

Sampling from pipes, pulsating flow problems, condensation. Infrared, thermal and magnetic methods and their errors. The Orsat and extended Orsat apparatus. Colour change methods.

9. COMBUSTION-TYPE INSTRUMENTS

Filament combustion 'explosimeters', hints on sampling. Gas calorimeters, inferential (Sigma type) and Boys' type, precautions and errors. Bomb calorimeter for liquid or solid fuels with particular reference to error estimation.

10. CASE STUDIES AND OTHER EXAMPLES

How to find nothing when there should be something. Interesting but irrelevant experiments. Investigating versus good designing. Over-broad conclusions from limited data. Misleading impressions.

Appendix 1 Residual Stresses, Prior Loads

Appendix 2 Further Thoughts on Fracture Testing

Appendix 3 Inertia Loads and Stress Waves - A Short Review

Appendix 4 Height Errors in Flow Measurement

Appendix 5 Optical Methods

Answers to Questions 


\section{PREFACE}

This book is intended for students of mechanical, chemical and other branches of engineering at universities or technical colleges. It should help them to benefit from laboratory work by encouraging a thoughtful, critical attitude and by indicating the wider context of basic experiments. This type of material is difficult to present and even more difficult to absorb when given in lecture form; it is hoped that lecture rs as well as students will welcome this selection. It is complementary to the well-established books on instrumentation, with a minimum of overlap.

The sequence has been arranged to suit students throughout their tertiary education, starting with material which can be followed on the basis of school-work, following on to those topics met early on in an engineering course. The later parts include material appropriate to project and research work. Detailed descriptions have been avoided, except in the case of gas analysis, in view of the limitations of space and the great variety of apparatus available for most of the other operations.

\section{ACKNOWLEDGMENTS}

The author is very grateful to Dr K. Martin of UWIST for his constructive criticism of the manuscript and to the University of Sheffield for the use of general facilities. Particular thanks are due to Mrs P. Windle, for typing and presentation, and Messrs Hallford and Francis for help with photographic work. 


\section{SYMBOLS}

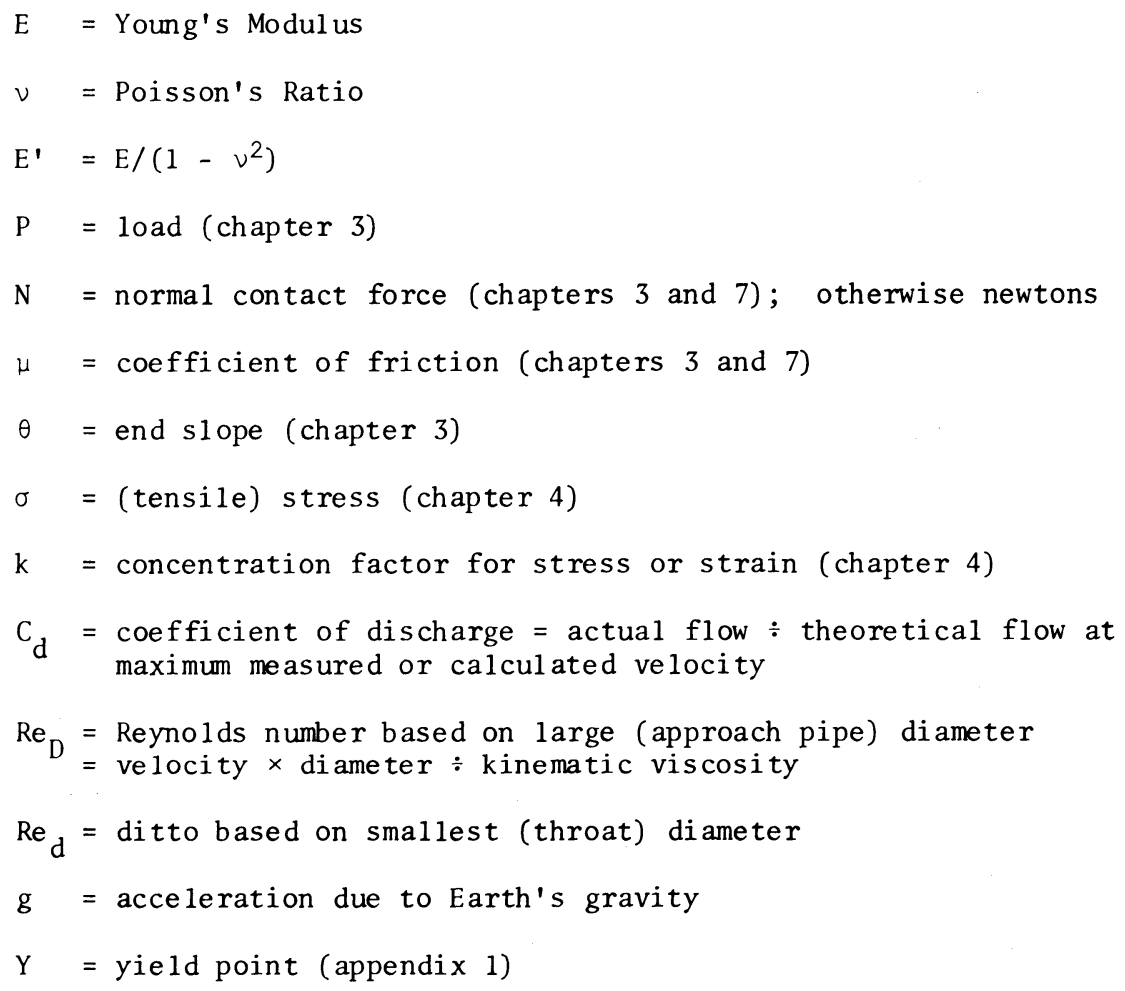

